\title{
The Globalization of Taxation? Electronic Commerce and the Transformation of the State
}

\author{
ROLAND PARIS \\ University of Colorado at Boulder
}

The anticipated growth of new communications technologies, including the Internet and other digital networks, will make it increasingly difficult for states to tax global commerce effectively. Greater harmonization and coordination of national tax policies will likely be required in the coming years in order to address this problem. Given that the history of the state is inseparable from the history of taxation, this "globalization of taxation" could have far-reaching political implications. The modern state itself emerged out of a fiscal crisis of medieval European feudalism, which by the 14 th and 15 th centuries was increasingly incapable of raising sufficient revenues to support the mounting expenses of warfare. If new developments in the technology of commerce are now undermining the efficiency of the state as an autonomous taxing entity, fiscal pressures may produce a similar shift in de facto political authority away from the state and toward whatever international mechanisms are created to expedite the taxation of these new forms of commerce.

Taxes not only helped to create the state. They helped to form it.... If the tax state were to fail and another form of providing for the wants of the community ensued... what we call the modern state would itself change its nature.

-Joseph Schumpeter (1918)

When there is no longer a territorial imperative, when the place of residence and the investment are no longer a given but a choice, when added value is generated in too abstract a fashion for its creation to be assigned a precise location, taxation is no longer a sovereign decision.

-Jean-Marie Guéhenno (1995)

Like 19th century settlers who pushed the American frontier westward beyond the writ of the U.S. government, the globalization of commercial activity has progressed much faster than the creation of international regulatory frameworks to govern this

\footnotetext{
Author's note: An earlier version of this article was presented at the annual conference of the American Political Science Association in San Francisco, California, August 30-September 2, 2001. My thanks to John Agnew, John Braithwaite, Benjamin Cohen, Daniel Drezner, David Hardesty, Eckhard Janeba, Robert Keohane, David Leblang, Catherine Mann, Joseph Nye, Louis Pauly, Jan Aart Scholte, Martin Shaw, Anne-Marie Slaughter, Hendrik Spruyt, Sven Steinmo, Steven Weber, and three anonymous reviewers for their helpful comments on previous drafts.
} 
activity. Commentators disagree over just how much the global economy should be regulated, but most acknowledge that existing rules governing trade, money, and other economic matters have not kept up with recent changes in global commerce, including the increased importance of multinational corporations, foreign direct investment, and trade in services and digital products. In many of these areas, international regulations are either very new or still in development. This article focuses on one area of global economic regulation that, while still embryonic, could turn out to be one of the most important developments in international governance in the coming decades: the rise of a global taxation regime.

Limited international coordination of national tax policies has been in place for decades, organized first by the League of Nations and later by the Organization for Economic Cooperation and Development (OECD). But new developments in international commerce stemming from advances in communications technology are calling into question the viability of existing systems of taxation and creating a need for greater international harmonization and collective management of national tax practices. In particular, international electronic commerce (ecommerce)—or business conducted digitally through the Internet or other electronic networks-represents a qualitatively new form of commerce that defies many of the assumptions upon which existing tax systems are based, including the notion that transactions can be located in physical space. The growth of international e-commerce will likely spur the movement toward international coordination of tax policy-or what I call the "globalization of taxation"-for two reasons: first, because states will not allow an ever-increasing volume of international digital commerce to escape taxation, and second, because states cannot effectively tax this new form of commerce without close cooperation with other states.

The political implications of the globalization of taxation could be far-reaching, the history of the state is inseparable from the history of taxation. The modern state, defined by the principle of exclusive sovereignty over a bounded territory, was born out of the fiscal crisis of medieval European feudalism, which by the 14th and 15 th centuries was increasingly incapable of raising sufficient revenues to support the mounting expenses of warfare. In the ensuing years, the state emerged as the dominant political organization in Europe in part because it extracted resources through taxation more efficiently than its rivals, including the Italian citystates, the Holy Roman Empire, and unreformed feudal states. In short, the modern state was able to survive and flourish because it made fiscal sense: it was a form of political organization that was particularly well-suited to taxing wealth and commerce.

If new developments in the technology of commerce-including the communications revolution, the Internet, and the rise of international e-commerce-are undermining the efficiency of the state as an autonomous taxing entity, we should expect fiscal pressures once again to alter the relationship between the modern state and other political entities. This is not to suggest that the state faces a fiscal crisis similar to that which destroyed European feudalism, or that the modern state will disappear or be supplanted by rival actors. Rather, it points to a continuing shift of taxing authority away from the exclusive domain of states and toward international forums and institutions, which are likely to play an increasingly important role in the design, and perhaps the administration, of tax policy.

This argument lends support to those who argue that we are witnessing a gradual but steady separation of state sovereignty from its territorial moorings (e.g., Murphy, 1996; Agnew, 1994; Ruggie, 1993). Although modern states formally retain their rights as sovereign entities in international law and remain by far the most important actors in world affairs, they are also increasingly sharing the stage with a diverse assortment of non-state entities-including international organizations, multinational enterprises, and formal and informal networks of govern- 
mental and nongovernmental agents—many of which possess "political authority" or the ability to set rules, allocate resources, and make decisions that constrain other actors in world affairs. As a result, "what were once domains of authority exclusive to state authority are now being shared with other loci or sources of authority" (Strange, 1996:82; see also Rosenau, 1990; Keohane and Nye, 2000). Certain commentators call this process the "internationalization of the state," or the gradual emergence of a decentralized, nonterritorial structure of authority in international affairs that performs functions traditionally associated with the role of the modern territorial state (e.g., Glassman, 1999; Wendt, 1994; Picciotto, 1990). Yet some functions are more central to the idea of statehood than others; and few functions are more central than taxation. To the extent that de facto taxing authority migrates upward from the state to an emerging global tax regime, the emerging "international state" will have gained an important additional function.

This article is divided into four sections. First, I examine the relationship between taxation and state sovereignty. Second, I map out the basic features of the existing international tax regime. Third, I show how changes in the technology and scope of international commerce-particularly the rise of digital commerce-pose fundamental challenges to existing systems of taxation and will likely necessitate greater international harmonization and collective management of national tax practices. Fourth, I consider the implications of my analysis for the future of the state, including the possibility that new fiscal pressures could be contributing to the growth of a nonterritorial "international state."

\section{Taxation and Sovereignty}

For several years, scholars have explored the fiscal implications of economic globalization: that is, whether the increasingly transnational character of global commerce is constraining the ability of states to set their own tax policies, to collect tax revenues, and to define their own domestic spending priorities. The most vibrant debate within this literature focuses on the question of whether increased capital mobility has caused a decline in national tax rates and revenues because states compete with each other for footloose international investment (Steinmo and Swank, forthcoming; Mosley, 2000; Mishra, 1999; Schulze and Ursprung, 1999; Garrett, 1998). Others have also studied the fiscal implications of "tax havens," or countries that seek to lure mobile capital by charging no tax (or only nominal tax) on foreign investment (Palan, 2002; Oxfam, 2000; Hampton, 1996; Picciotto, 1992: chaps. 6,7). Much less attention, however, has been paid to the question of whether changes in technology and scope of international commerce are creating pressures for the globalization of taxation, or movement toward greater international harmonization and coordination of national tax policies.

As we shall see below, a rudimentary international tax regime has existed since the 1920s, comprising a network of bilateral tax treaties that set out rules for taxing individuals or corporations whose activities cross international borders. Because these rules cover a relatively limited set of tax issues, states have traditionally retained near-complete autonomy to devise their own tax systems and policies. By a "globalization of taxation," I am referring to the possibility that states will be required to expand the scope of these rules-in effect, pooling their sovereign powers over taxation-in order to manage the more complex jurisdictional disputes and tax-collecting problems that arise from the increasingly transnational character of international business. Under a globalized tax system, important elements of national tax policy would be devised, and perhaps even administered, in collaboration with other states. Any significant pooling of national taxation powers could have potentially far-reaching implications for our understanding of state sovereignty, not only because the state itself came into existence and achieved 
dominance in world politics largely because of its ability to collect taxes, but also because taxation remains a central function and prerogative of the modern state.

Until the late Middle Ages, political authority in Europe (where modern states eventually emerged) was not based on the sovereignty principle of exclusive authority over a bounded territory; rather, it was a labyrinth of overlapping and multiple political obligations that centered around personalized feudal relationships between lords and vassals (Ruggie, 1993:149-151; Jackson, 1999:435-438). Nor did taxes in the current sense of the term exist during this time; instead, feudal rulers including kings were expected to live off rents, fees, and payments from their personal holdings (van Creveld, 1999:147). But these sources of revenue soon became inadequate as developments in weapons technology (including the pike and longbow) and the need for larger armies increased the costs of warfare (Bean, 1973:212-213; Webber and Wildavsky, 1986:223). In response to these growing financial demands and the limited supply of revenue from feudal rents, many rulers obtained credit from merchants and bankers, but borrowing only postponed the problem because bankers normally demanded secured pledges of future income against their loans (Anderson, 1974:44).

Ultimately, almost all medieval monarchs in Europe turned for financial help to their Estates-or assemblies of subordinate nobles-which had traditionally been called upon very infrequently to provide special payments, usually in cases of emergency and for limited time periods. By the late Middle Ages monarchs used the Estates increasingly as a regular source of income to defray their rising, routine expenditures. The Estates often insisted on collecting and disbursing these taxes themselves, which led to the growth of Estate tax systems across Europe, administered by semipermanent bureaucracies. These systems, which reached their peak during the latter part of the 16th century, effectively became separate powers. Not surprisingly, a battle for control of these taxing institutions unfolded, pitting the Estates against the monarchs. Everywhere but England, the monarchs won and the Estates subsequently declined as a political counterbalance to the authority of the monarchs, who gained control of the centralized tax systems that became the foundation of modern bureaucratic states (Braun, 1975:270).

Tax collection was, in fact, the central force in the creation of a public service and the centralization of political power in Europe. In France, for example, the monarchy conferred increasing powers on royal tax collectors in the provinces, including police and judicial powers necessary to put down popular revolts against the collection of taxes (Strayer, 1970:30-31; Ardant, 1971:455-457). The demands of taxation thus led the French monarchy to exercise more centralized and direct control over related areas of public life, including security and justice (Ardant, 1971:455-457). This process resulted in greater administrative homogeneity throughout the country, which "served to mold the heterogeneous French provinces into a unified state" (Webber and Wildavsky, 1986:208). Meanwhile, the perceived need for larger armies to fight nearly annual campaigns increased the demand for tax revenues and led to the growth of a permanent corpus of government officials at the national and local levels (Ertman, 1997:77), as well as sharp increases in government revenues (Bean, 1973:212-213; Van Creveld, 1999:155). Centralization of political authority, in other words, allowed for more extensive and coordinated taxation within the territories of the emerging modern states, which in turn provided central authorities with an enhanced military, fiscal, and administrative apparatus that they could use to extract further resources (Poggie, 1978:63).

Rival political forms such as the Holy Roman Empire and the smaller city-states south of the Alps fared less well as tax-collecting entities. The Holy Roman Emperor never gained effective control over the emerging commercial power centers of German towns and cities, and consequently was not capable of extracting regular taxes from his Estates, nor was the loose conglomeration of German 
principalities that succeeded the Empire-the Hanseatic League-sufficiently centralized to establish a system of direct taxes (Spruyt, 1994: chap. 6; Braun, 1975:249-250). While the Italian city-states did develop in a similar direction as the modern territorial state (with more or less centralized control over a bounded territory) and became adept at taxing, the small size of the city-states limited their revenue base (Spruyt, 1994:145, 155-158). The superior abilities of the modern territorial state in obtaining revenues from taxation and in fielding larger armies contributed to the eventual demise of other forms of postfeudal political organization in Europe through warfare and emulation, including the Holy Roman Empire and the Italian city-states (178).

Thus it was more than just the consolidation of centralized authority that made the modern state a successful taxing entity; it was also the state's exclusive control of a relatively large territory within which commerce and wealth could be taxed. But this explanation also implies that commerce and wealth had certain properties: they were sufficiently immobile and linked to particular territories that a territorially bounded political authority such as the modern state would be able to use its administrative apparatus, backed ultimately by threats of coercion, to impose taxation upon them. Thus the modern territorial state emerged as the dominant political form in part because it made fiscal sense at the time: the logic of territorial exclusivity upon which it was based was well-matched to the demands of taxing territorially rooted wealth and commerce, and as a result the state was particularly good at collecting taxes.

Put differently, the relationship between taxation and the emergence of the modern state was one of "mutual constitution": taxes made the state, and the state made taxes (Hoffman and Norberg, 1994:303). One of the earliest scholars to write about this connection was Joseph Schumpeter, who argued in 1918 that fiscal conditions influence the evolution of political forms-specifically, by favoring those forms that are best-suited to raising revenues through taxation. The feudal system failed, he argued, for precisely this reason: it could not compete with the emerging modern state as a revenue-raising entity. But this logic also led Schumpeter to the conclusion that the modern state itself could be outmoded as a taxing instrumentif economic or technological conditions were to change in ways that made the institutional form of the modern state ill-suited to the requirements of effective taxation. Ultimately, he argued, political authority will shift to whatever institutional forms are best designed for the task of assessing and collecting taxes.

The centrality of taxation to the development of the modern state, and Schumpeter's related analysis of the fiscal sources of institutional evolution, suggest that any significant diminution of the modern state's capabilities as a taxing entity could have important political, not merely economic, consequences. What if, for instance, contemporary changes in the technology, mobility, and scale of commerce made it increasingly difficult for a territorially bounded political form such as the modern state to collect taxes within its territory and at its borders? In that case, states might respond by coordinating their taxation arrangements with other states-in effect, "globalizing" the management of tax policy. In doing so, states might successfully preserve their collective capability to tax, but they would also lose some measure of autonomy as taxing entities, as some small but real amount of political authority over taxation would shift away from individual states and toward whatever international regulatory arrangements were established to coordinate this taxation.

This type of relocation of authority is common in international affairs, occurring whenever states create a global regulatory arrangement in which they effectively pool their sovereign powers. But with the possible exception of national defense, no policymaking competence is more central to the idea of the modern state than taxation. The globalization of taxation would represent a historic shift in the relative balance of political authority between individual states and the decentralized 
network of global regulatory arrangements that are increasingly performing functions traditionally associated with the modern state. But is there any evidence that the globalization of taxation is likely to occur? In what follows, I first describe the principal elements of the existing international taxation regime, and then I show how changes in the technology and scope of global commerce-particularly the rise of international electronic commerce-are challenging existing methods of taxation in ways that are likely to bring about a globalization of taxation.

\section{The International Tax Regime}

Efforts to build a rudimentary international regime in the area of taxation gained momentum in the years immediately following World War I, driven primarily by concerns about "double taxation," or the possibility that different countries would attempt to tax the same cross-border transactions or income. In 1921 the League of Nations commissioned four experts in public finance to study the economic consequences of double taxation. After the experts concluded that double taxation interfered with "economic intercourse and...the free flow of capital" and prevented an "equitable distribution of burdens" among taxpayers (quoted in Mann, 1997), the League drafted several "model treaties" on double taxation, which provided templates for bilateral treaties that countries could negotiate in order to clarify their respective rights in the taxation cross-border transactions and income. After World War II, the OECD continued the League's work and eventually published its own Model Income Tax Convention in 1963, ${ }^{1}$ which today remains the cornerstone of the international tax regime: most of the 1,500 or so bilateral tax treaties in the world are "substantially similar" and are based on the principles set out in the Convention (Forst, 1997).

The Model Income Tax Convention attempts to reconcile two competing approaches to taxing income. The first approach-the "residence principle"holds that countries have a right to tax the income of people or commercial entities that reside within their borders. The second approach to income taxation-the "source principle"-holds that countries can tax income that arises from sources in that state, regardless of whether the parties involved in the transaction are residents in that state. Most countries employ both approaches to taxation simultaneously: they tax the income of resident individuals and companies, and they tax income generated within their territory. This practice, however, raises the possibility of double taxation, since income generated by nonresidents could conceivably be taxed both by the country from which the income derives (the source jurisdiction) and by the income-generator's home country (the residence jurisdiction).

To avoid double taxation, the OECD Convention offers the following formula: Countries can tax income based on both source and residence, but they should also compensate their own residents-through tax deductions or credits-for income taxes paid to foreign governments. In addition, the Convention sets out criteria to determine residency (individuals are deemed to reside in the country in which they have the strongest "personal and economic links"), establishes guidelines for the taxation of nonresident businesses (whose income may be taxed as long as it derives from a "permanent establishment"-defined as any fixed place of business, such as a branch, office, or factory-maintained in the taxing country), and clarifies the differences between various types of income. ${ }^{2}$ Together, the OECD Convention and the network of bilateral tax treaties, which are based largely on the Convention, make up the core of the current international tax regime.

\footnotetext{
1 "Articles of the OECD Model Tax Convention on Income and on Capital," April 29, 2000, reproduced on the OECD website: http://www.oecd.org/daf/fa/treaties/MTCArticles.pdf.

${ }^{2}$ The definition of "permanent establishment" excludes facilities that are solely maintained for the "storage, display or delivery of goods or merchandise."
} 
Four features of this regime stand out. First, it presupposes a clear link between geography and commerce: allocating taxation rights under the current regime involves locating the geographical source of income, or the residency status of those engaged in income-producing activities, or both. (It should be noted that the OECD Convention thus did not invent the linkage between territory and tax, but simply reaffirmed the long-standing territorial and state-based character of taxation.) Second, it is a "weak" regime: there is no requirement that states implement the OECD guidelines, no enforcement or monitoring of state behavior, no international mechanism to resolve international disputes, and no centralized system for sharing information that states could use to coordinate their taxing efforts if they chose to do so. Third, it is a "narrow" regime: the guidelines focus almost exclusively on direct (or income) taxes, and largely ignore indirect, or consumption taxes (for example, sales tax or value-added tax), which in fact represent an increasing share of national tax revenues among the members of the OECD. Fourth, it is primarily a bilateral, not multilateral, regime: although the Convention was negotiated multilaterally among OECD members, implementation of the Convention involves the negotiation of bilateral treaties between pairs of states-unlike, for example, the multilateral mechanism that governs international trade. In short, the international tax regime is geographical in conception, limited in scope, and decentralized and voluntary in application. These characteristics have led some commentators to claim that it should not be considered a regime at all (Rosenbloom, 2000). This position, however, is rejected by most tax experts, who argue that the ubiquity of bilateral tax treaties based on the OECD Convention highlights the existence of a common set of principles, norms, rules, and decision-making procedures around which actors' expectations have converged in the area of taxation. ${ }^{3}$ Yet in spite of this uniformity, the regime does not impinge very much on the autonomy of states to design and manage their own taxation policies: it is, fundamentally, a minimalist set of arrangements designed to reduce double taxation on cross-border income.

Recently, members of the OECD have expressed concern that the existing tax regime may be inadequate to cope with taxation problems arising from the "accelerating process of globalization of trade and investment" (OECD, 1998b: para. 21). In particular, the diminishing costs of transportation and communication are making it easier for corporations and individuals to shelter investments and income in offshore tax havens, and raising fears of a possible "race to the bottom" in which all jurisdictions might drastically reduce taxes in order to attract investment, thus eroding the global tax base. In 1996, OECD ministers and the Group of Seven industrialized nations issued separate communiqués condemning "harmful tax competition" and calling on the OECD to "vigorously pursue its work... aimed at establishing a multilateral approach under which countries could operate individually and collectively to limit the extent of these practices" (quoted in OECD, 1998b: para. 2). Two years later, the OECD unveiled a plan aimed at combating tax competition, the main elements of which included evaluating countries' tax policies for evidence of "harmful tax measures," publishing a blacklist of tax havens that refuse to implement reforms, identifying punitive measures that countries could take against these tax havens, and creating a forum within the OECD to serve as an information clearinghouse and coordinator of national measures against tax havens. ${ }^{4}$

It remains to be seen what will come of these plans, but current proposals would involve a significant broadening of the international tax regime beyond its longstanding focus on double taxation, and into the realm of appropriate national tax

\footnotetext{
${ }^{3}$ In other words, international tax arrangements do meet the most commonly accepted definition of an international "regime." See Krasner, 1982; Avi-Yonah, 2000a.

${ }^{4}$ OECD, 2000. For an analysis of this initiative see Samuels and Kolb, 2001.
} 
rates, along with a new emphasis on multilateral action to uphold the international tax regime. In addition, as we shall see below, the OECD has conducted extensive consultations with member states, business groups, and other international organizations on the particular challenges that the rise of electronic commerce pose to the existing international tax regime, ${ }^{5}$ and in March 2002 announced the creation of a new "International Dialogue on Taxation" to serve as a central communications hub for national governments and international agencies on issues of tax policy and tax administration, including the effects of economic globalization on existing tax practices (OECD, 2002).

\section{E-Commerce and the Globalization of Taxation}

There are good reasons to believe that, the rise of global electronic commerce will spur a substantial broadening and strengthening of the international tax regime. This is not to say that states will cease to collect taxes themselves, or that a supranational taxing authority will be created, but rather, that the rise of ecommerce is likely to precipitate a shift in the relative balance of de facto taxing authority from the domestic to the international level as states come to realize that technological changes in the nature of commerce require higher levels of international tax policy coordination. This conclusion rests on several premises: (1) that international e-commerce will continue to grow; (2) that the spread of this commerce will challenge existing systems of taxation; (3) that national governments will ultimately demand the taxation of digital commerce; and (4) that the effective taxation of electronic commerce will require extensive international coordination. I defend each of these premises below.

\section{Premise 1: International E-Commerce Will Continue to Grow}

The total value of worldwide e-commerce increased from near zero in the early 1990 s to at least, $\$ 132$ and perhaps as much as $\$ 657$ billion in $2000 .^{6}$ The low estimate is roughly equivalent to the gross domestic product (GDP) of Finland; the high estimate tops the GDP of Canada. ${ }^{7}$ The 2000 downturn in the U.S. technology sector does not appear to have reversed this trend. Business-to business electronic commerce, in particular, has continued to burgeon (see Figure 1). Online retail sales have also grown rapidly: In the midst of recession, retail e-commerce within in the United States grew by a healthy 19.3 percent in 2001, compared to only 3.3 percent growth in non-electronic commerce during the same year (United States Department of Commerce, 2002).

Although and estimated 60 percent of global e-commerce is currently conducted within the borders of the U.S. alone, most analysts expect this situation to change quickly as more people continue to gain access to the internet (see Figure 2), including those living in the lucrative markets of Western Europe and East Asia. Even in Latin America, the number of Internet users is expected to jump from 15 million in 2000 to an estimated 75 million in 2005 (Latin Finance, 2001). If current trends hold e-commerce within the United States will fall below 50 percent of the worldwide total in 2004 and the phenomenon of electronic commerce will become considerably more global (Forrester Research, 2002). ${ }^{8}$ Even at this relatively early

\footnotetext{
${ }^{5}$ For a comprehensive review of the OECD's activities in this area see OECD, 2001

${ }^{6}$ For a summary of estimates from several sources, see eMarketer, 2001. The estimates vary widely due to definitional and technical issues involved in measuring the Internet economy, which are described in OECD, 1997.

${ }^{7}$ GDP figures are from the OECD's online database, http://www.oecd.org/std/gdp.htm (accessed 19 August 2001).

${ }^{8}$ As several commentators have pointed out, the spread of the Internet nevertheless likely to leave poorer regions and groups disconnected, thereby creating a "digital divide" in the world's population.
} 


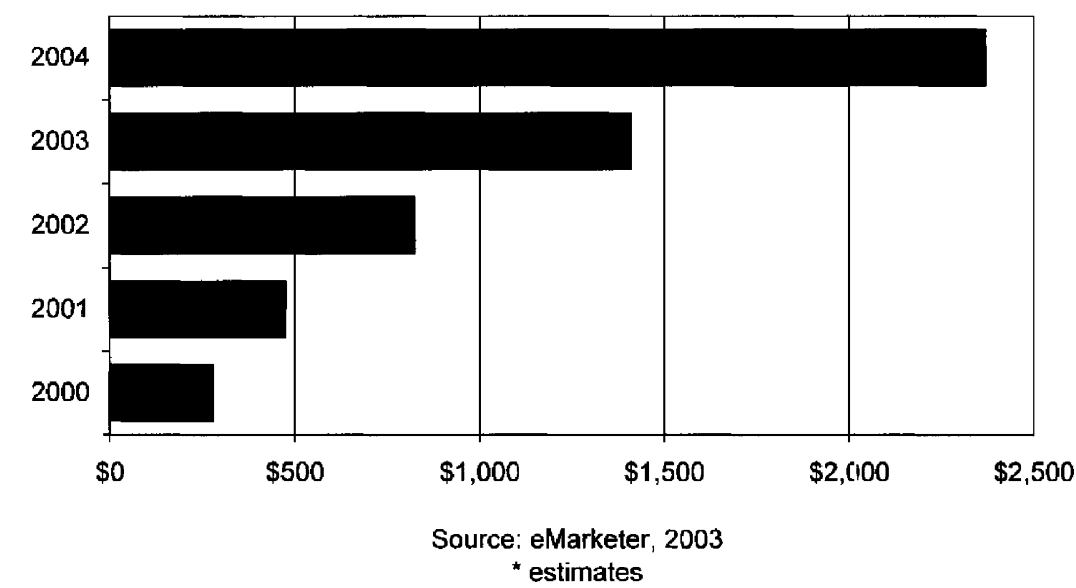

FIG. 1. Worldwide Business-to-Business E-Commerce Revenues, 2000-2004 (in billions).

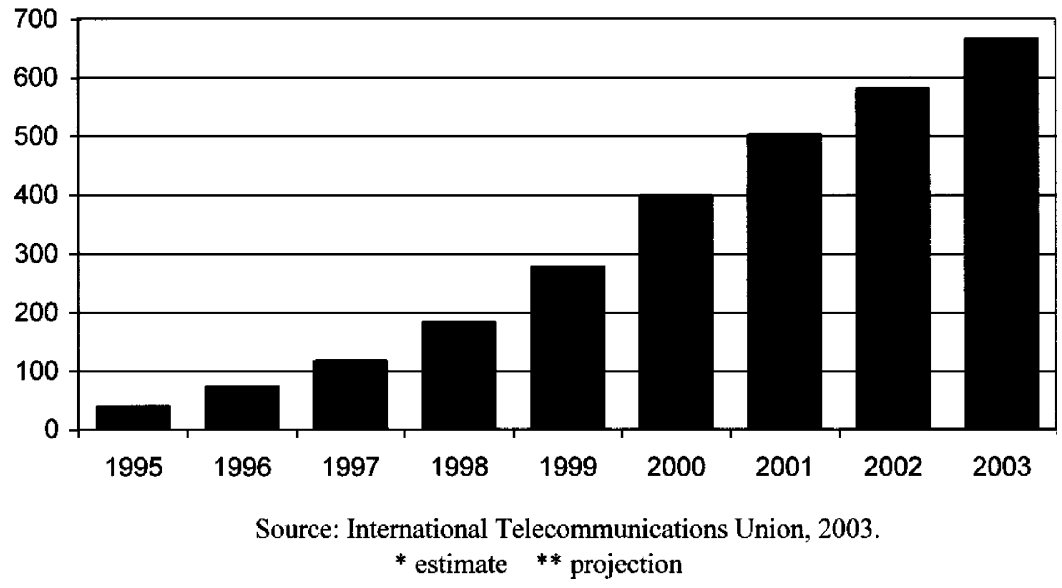

FIG. 2. Worldwide Number of Internet Users (in millions).

stage in the development of international e-commerce, cross-border transactions have become common place. $^{9}$ Specific predictions vary, but most analysts expect that both the volume and value of international digital commerce will continue to expand for the remainder of this decade and beyond, probably outpacing growth in the "traditional" economy by a wide margin. Given the steadily increasing numbers of people with access to the Internet, the investments being made by companies to make their services and goods available online, the relative lack of distance barriers to electronic communication, and the "huge scope for cost-cutting that the Internet offers" to small and large business, the continued growth of international electronic commerce seems very likely (Economist, 2001a).

\footnotetext{
${ }^{9}$ For example, 58 percent of consumers who were polled in eleven countries (other than the U.S.) in 2000 said that they had made at least one purchase from an online business in a country other than their own (Ernst and Young, 2001:51)
} 


\section{Premise 2: The Growth of E-Commerce Will Challenge Existing Tax Systems}

The question of how e-commerce might impact existing tax systems is attracting the attention of economists, political scientists, tax lawyers, and policy analysts, both inside and outside of government. ${ }^{10}$ As noted above, most national tax systems-as well as the international tax regime on which many of these systems are basedassume that commercial activities can be linked to a particular territory. Electronic commerce challenges this assumption because it is inherently nonterritorial. "Net addresses," writes Stephen Kobrin, "are relational organizational constructs and often do not reflect physical location. Servers routinely shift clients from 'location' to 'location' to balance loads; a buyer can log on to any server remotely" (Kobrin, 2000;see also Johnson and Post, 1999). Consequently, the task of locating ecommerce transactions in physical space-and of identifying the participants in this transaction-can be difficult or even impossible in certain circumstances, given current technology. This disjuncture between the geographical foundations of modern taxing systems on one hand, and the nonterritorial character of e-commerce on the other, is at the heart of the challenge that e-commerce poses to taxation.

Consider, for example, current methods of direct taxation, which includes personal and corporate income tax. We noted earlier that there are two prevailing approaches to direct taxation: one based on the source principle; another based on the residence principle. In practice, states tax income on both source and residence, and establish bilateral tax treaties based on the OECD Model Income Tax Convention to avoid double taxation. Taxation based on the source principle, however, presupposes that taxing authorities can determine the geographical source of income, while taxation on the residence principle requires information about the identity and residency status of those engaged in income-producing activities. Electronic commerce breaks down the necessary and clear connection between territory and commerce, and makes this type of information more difficult to obtain, thus complicating the task of taxing income based on source or residence.

A hypothetical electronic transaction illustrates these complexities: Assume that an e-commerce firm has its headquarters in Country "A," and the company accepts customer orders through an Internet website that it maintains in Country "B." The website then transmits orders to the company's sales department in Country "C." Suppose, now, that a customer who resides in Country "D" places an online order through the company's website. The order is channeled electronically through a chain of servers in any number of locations, ultimately arriving at the company's website in Country "B," which in turn transmits the order to the sales office in Country "C." Let us further assume that the company has a storage facility in yet another jurisdiction-Country "E." After approving the order, the sales office arranges for shipment of the product from the storage facility in Country "E" to the customer. If the product is digitized-that is, if it comprises electronic information only, such as computer software-then it might be delivered electronically directly to the customer. If so, the consumer could receive the product anywhere on the planet where there is an Internet access point. The company, in other words, has no idea of where in the physical world its digitized product will end up. Furthermore, if the product is digitized, the company's "storage facility" could amount to nothing more than a computer hard drive or server, and could even be a mobile laptop computer, or a mobile server, or an array of redundant "mirror" servers located in several different jurisdictions. In this case, the "storage facility" from which the company's product is delivered might be just as mobile as the customer receiving the product.

\footnotetext{
${ }^{10}$ For example, Mann, 2000; Avi-Yonah, 2000a, 2000b, 1997; Doernberg and Hinnekens, 1999; McClure, 2000, 1997; Kobrin, 2000, 1999a, 1999b; Deloitte and Touche, 1999; Government of Canada, 1998; Government of Australia, 1999, 1997; United States Government, 1996; OECD, 1998a.
} 
This example, though more complicated than many e-commerce transactions today, is not far-fetched. Already, customers can download software products, for example, onto their laptop computers by plugging into Internet connections in international airports or on international flights. Furthermore, the mobility of Internet users will be even greater with the anticipated spread of wireless Internet communications (which is already well under way in Japan-see Figure 3) (see also Economist, 2001b; Financial Times, 2002). What the hypothetical transaction illustrates are some of the difficulties involved in determining the geographical source of income, and the residency status of those engaged in income-producing activities, within the world of digital commerce. Where is the source of the income in the above example? Is it Country "A" where the company has its headquarters, Country "B" where the company has its website, Country "C" where the sales office processed the order, or is it the country from which the product was delivered (assuming that this location can be identified)? Under current rules, much would depend on the definition and application of the concept of "permanent establishment." To the extent that income-generating activities took place in a country where the company had a permanent establishment or a "fixed place of business" that country would be entitled to tax the profits attributable to the establishment. The problem in applying this standard, however, is not only determining how to apportion the company's profits and tax liability across a multitude of jurisdictions-a task that would be immensely complex in itself-but also the possibility that an e-commerce company might not have a fixed place of business anywhere. The fact that products can be delivered from mobile "storage facilities," and that a company could be managed from several different locations simultaneously, undermines the assumption of fixedness that is at the core of the permanent establishment concept. "The Internet," writes the Australian Tax Office, "provides an environment where automated functions, by their very nature, may be able to undertake a significant amount of business activity in a source jurisdiction with little or no physical activity or participation in the economic life of any jurisdiction anywhere (Government of Australia, 1997:16).

Recognizing this problem, the OECD's Fiscal Affairs Committee has recommended revising the concept of "permanent establishment" in the Model Tax Convention. As part of its ongoing efforts to investigate the tax implications of

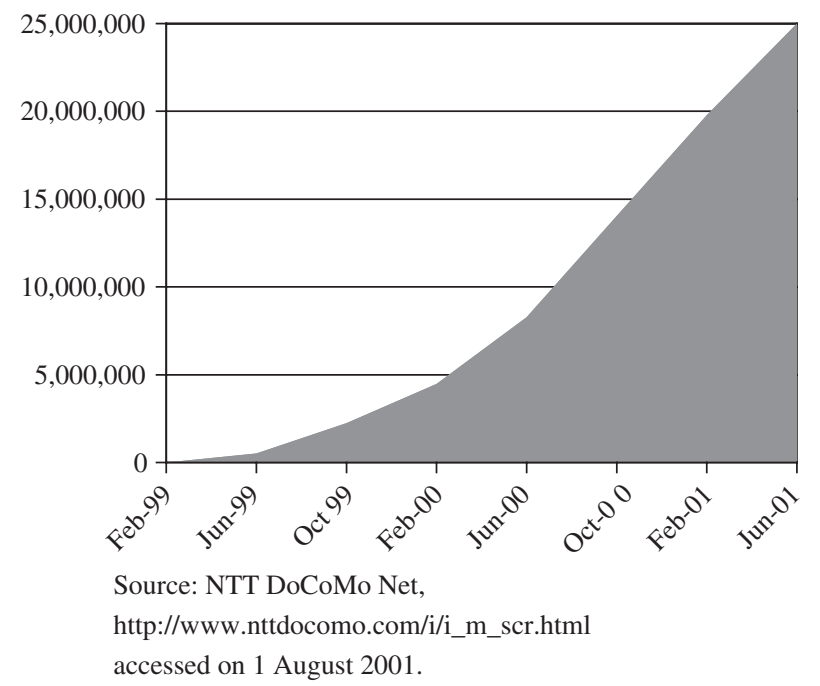

FIG. 3. Subscribers to NTT-Japan's Mobile Internet Service (the largest of three mobile Internet Services in Japan). 
international e-commerce (OECD, 2001), the Committee decided in December 2000 that "computer equipment, such as a server" should be treated as a permanent establishment only if this equipment performs "an essential or core part of the business activity of the enterprise," and that websites, website hosting arrangements, and Internet service providers should generally not be treated as permanent establishments for tax purposes (OECD, 2001: chap. 4). This definition, however, does little to resolve the problem, since many of the stages in the hypothetical business transaction described above would not meet the threshold of "permanent establishment" under the new OECD guidelines, and therefore would not be taxable. Indeed, any amount of tinkering with the concept of permanent establishment seems doomed to failure as long as the concept remains rooted in the idea of geographical fixedness-and the OECD shows no sign of abandoning this concept anytime soon. The same problem besets efforts to apply the test of "place of effective management" to determine tax liability for firms engaged in ecommerce: because "virtual" firms may perform management functions in several jurisdictions simultaneously, and because of the increased mobility of businesses and managers, existing tests of "effective management" are generally unsuitable to cross-border electronic commerce-as the OECD readily acknowledges (OECD, 2001:149-157).

Moreover, even if the OECD were to invent a standard that successfully identified the physical location of purely electronic transactions, along with the identity and residency status of those involved in the transaction, the assessment and collection of direct taxes might still be very difficult, for several reasons. First, the complexities of apportioning tax liability on a "virtual" business across numerous taxing jurisdictions would likely require a detailed set of jurisdictional rules that do not as yet exist. In addition, there would be a need for some kind of system for applying these rules to individual cases, and for resolving inevitable inter-jurisdictional disputes, which also does not exist. In the words of one U.S. Treasury official: "Our traditional rules for determining each country's jurisdiction to tax and for determining the source and character of taxable income will come under increasing pressure" due to the growth of electronic commerce. ${ }^{11}$ Given the reasonable expectation that advances in communications technology will permit businesses to become even more decentralized and mobile in the future, international disputes over the jurisdiction to tax "virtual" business profits are likely to become increasingly common-and complex. Second, collection of these taxes might be difficult in cases where companies liable for tax payments have no physical presence or assets in the taxing country, and therefore nothing for the taxing country to seize as a method of compelling payment. ${ }^{12}$

Indeed, these very conditions make it easier for companies to evade taxation by maximizing their mobility and decentralization, and by minimizing their physical presence and assets in jurisdictions with the most aggressive taxation policies-a strategy facilitated by advances in communications technology. This strategy is being publicly touted by business consulting firms, such as Ernst and Young, which offered the following advice in its 2001 report on global online retailing:

[T]he Internet allows geographically neutral activities, such as purchasing and/or sales transaction processing, to be hosted by a separate company that can capture service fees in the low-tax jurisdiction and, accordingly, reduce taxable income in other high-tax jurisdictions in which the business operates. Income from

\footnotetext{
${ }^{11}$ Acting Assistant Secretary for Tax Policy Jonathan Talisman. See Talisman, 2000.

${ }^{12}$ In addition, countries currently have no practical way of compelling companies to pay taxes if the company has no tangible assets that could potentially be seized within the territory of the country. For example, there is currently no reliable method of blocking access to commercial websites that refuse to pay taxes; and although customs officials can block tangible products from entering a country, digital products do not physically "cross" frontiers and are therefore not subject to border controls.
} 
intangibles such as domain name, software capabilities, customer and supplier lists, distribution rights, trademarks, and trade names should also be examined since it may be possible to capture royalty fees in a low-tax jurisdiction. In general, the more a company shifts business risks or functional activities to lowtax jurisdictions, the greater the savings it may realize.

To be sure, this is not an entirely new phenomenon: the globalization of production processes has long involved companies relocating some or all of their activities in order to minimize costs. But as The Economist points out, "in the coming decades electronic commerce-combined with the growing ease with which firms can shift their operations from one part of the world to another-will make it ever easier for people to flee countries where taxes are high, or to evade tax altogether by doing business in cyberspace" (Economist, 1997:1). Further compounding this problem is the fact that the Internet makes it harder for countries to keep track of income generated in their territory, since no government can be aware of all or even most of the websites in the world that offer products or services to their residents. E-commerce also leaves less of a "paper trail," such as invoices and receipts, which tax authorities often use to track down and verify conventional transactions; and even when electronic records are available, they are more subject to tampering than are paper records (Tanzi, 2000:7; see also McClure, 1997:318; Government of Canada, 1998). Nor is it always possible to identify the legal entity-or physical taxpayer-associated with a particular Internet website (McClure, 2000:56; Government of Australia, 1997).

Many of these challenges also apply to indirect or consumption taxes on ecommerce, including sales taxes, goods and services taxes (GST), and value-added taxes (VAT). ${ }^{13}$ Like direct taxes, the administration of indirect taxes presupposes that tax authorities are able to (1) identify transactions when they take place; (2) identify the parties involved in the transaction and their physical location; and (3) if necessary, follow a "paper trail" in order to audit these transactions-all of which are conditions that e-commerce calls into question, for the reasons noted above. Moreover, one further difficulty that tax authorities face in applying the VAT is to determine the precise value of the different components of a single production process, and to identify the specific jurisdiction in which each "value-addition" takes place (Mann, 2000:88). Once again, this is not an entirely new problemtransnational enterprises with globalized production systems have long been required to place a monetary value on the constituent parts of their production processes for tax purposes-but the development of new communications technologies has already made, and will continue to make, this task considerably more complicated. In the case of companies that develop software products, for example, simultaneous collaboration on a single product among programmers in several different jurisdictions challenge the notion that it is possible to attribute specific "value-addition" to a particular taxing jurisdiction, particularly if the software product is exchanged back and forth among programmers (who may themselves be mobile) by electronic means as the product is developed.

For all of these reasons, the spread of e-commerce poses a serious challenge to existing systems of direct and indirect taxation. Although the difficulty of taxing electronic commerce will vary according to the particular circumstances of this commerce, ${ }^{14}$ prevailing methods of national taxation-and the existing interna-

\footnotetext{
${ }^{13}$ Sales tax and GST are normally charged on the final sale value of a good or service, whereas VAT is typically applied at each value-adding stage in the development of a good or service.

${ }^{14}$ Intra-firm flows and business-to-business transactions, for example, which make up the bulk of electronic commerce today, are in principle easier to tax under existing arrangements than business-to-consumer transactions, because the identity and physical location of incorporated businesses are generally easier to determine than those of private online consumers. Nevertheless, even the growth of intra-firm and business-to-business e-commerce raises problems for national tax authorities, including, as noted above, the problem of identifying the specific jurisdiction in which "value addition" takes place, and the difficulty of locating electronic transactions (including business-tobusiness transactions) in physical space.
} 
tional tax regime-were designed for a world in which both commercial transactions and the creation of income could be traced to specific territorial jurisdictions. But in the realm of electronic commerce, these assumptions are no longer valid. As long as e-commerce remains a relatively small part of the global economy, the mismatch between e-commerce and the current tax regime will remain a matter of relatively minor significance. But as digital transactions become more common, national governments will find it "increasingly difficult to collect taxes" (Kobrin, 2000:23). This is the greatest challenge that e-commerce poses to tax authorities: that the disjuncture between the nonterritorial character of ecommerce and the territorial assumptions of the current tax regime will result in a growing proportion of commerce that effectively avoids taxation.

\section{Premise 3: National Governments Will Demand the Taxation of E-Commerce}

Despite the hopes of some that the Internet and Internet-based commerce will remain free of government regulation including taxation, the anticipated growth of e-commerce in the coming years (premise 1) and the challenge that e-commerce poses to existing tax systems (premise 2) will likely prompt national governments to demand the effective taxation of sales and profits arising from e-commerce. As we noted earlier, member states of the OECD have spoken out against the effects of "harmful tax competition," or the ability of companies and individuals to shelter wealth in low-tax or no-tax jurisdictions, which many countries fear will erode national tax bases and revenues. Similarly, even though the scale of international ecommerce remains small, governments are already expressing concern about the possibility that the anticipated growth in electronic commerce will reduce their ability to raise the tax revenues "required to meet the legitimate expectations of citizens for publicly provided services" (OECD, 1998a). China, for instance, has threatened to impose a special tax on electronic commerce (Enos, 2000a), the European Union and New Zealand are undertaking fundamental changes to their methods of collecting value-added tax largely in response to the rise of international e-commerce, ${ }^{15}$ while other countries including Australia have concluded that "tax revenues are likely to be affected" by e-commerce and are now considering possible policy responses (Government of Australia, 1997). These concerns are likely to intensify as the volume of e-commerce expands.

The domestic debate over e-commerce taxation within the United States offers some indications of how this issue may unfold at the international level. Even though electronic transactions currently account for only one or two percent of retail sales revenues in the U.S. (United States Department of Commerce, 2001; Boston Consulting Group, 2000), states' governors are increasingly worried about the impact of inter-state electronic commerce on state tax revenues. Sales taxes have typically yielded about one-third of state tax revenues, and approximately 10 percent of local government tax revenue, or roughly one-quarter of combined state and local tax revenue (Mikesell, 2000). Under current regulations, businesses are required to collect and pay state sales taxes if they maintain a substantial presence within the taxing jurisdiction of the state. In 1992, the U.S. Supreme Court ruled that mail-order firms were not required to collect taxes from customers in states where they have no physical presence or "taxable nexus," which is normally defined as an office or a representative of the vendor, and is roughly analogous to the "permanent establishment" standard within the international tax regime. ${ }^{16}$ Thus, a state has no legal right to collect tax on purchases from out-of-state vendors, including online businesses, if these vendors have no taxable nexus within the state.

\footnotetext{
${ }^{15}$ On the European Union's efforts, see below. On New Zealand, see Howie, 2000.

${ }^{16}$ Quill Corp. v. North Dakota, summarized in Hellerstein, 1997:437-441.
} 
There is a growing consensus that e-commerce will take an increasingly large bite out of state and local tax revenues in the United States in the years to come. Although the General Accounting Office (GAO) of the U.S. Congress calculates that losses in state and local tax revenues due to Internet sales in the year 2000 were relatively small-less than 2 percent of aggregate general sales tax revenues-the GAO also projects that by 2003 "tax losses...could present significant challenges for state and local government officials," according to some scenarios (United States General Accounting Office, 2000). The Congressional Budget Office similarly maintains that tax erosion due to e-commerce "could be large enough to compel many states to choose between reducing spending or seeking new revenues through higher tax rates or new taxes" (Woodward, 2001). Economists Donald Bruce and William Fox offer a more precise prediction-that electronic transactions will result in approximately $\$ 10.8$ billion in additional tax revenue losses within the United States in 2003 alone (Bruce and Fox, 2000)—while the market research firm Jupiter Media Metrix estimates that tax losses for state and local governments could top $\$ 7.7$ billion in 2005 (reported by Enos, 2001).

Despite the uncertainty of these projections, the National Governors' Association (NGA) has concluded that e-commerce poses a threat to state tax revenues, and is vigorously lobbying the U.S. Congress to pass legislation that would permit states to impose sales tax on remote sales. One of the NGA's arguments-beyond the anticipated loss of tax revenue-is that e-commerce retailers enjoy an unfair advantage over non-electronic "bricks-and-mortar" businesses, or fixed enterprises that do not engage in remote sales and are therefore required to pay sales tax. The NGA proposes the following remedy: Online sellers should be required to collect sales taxes and to remit those taxes to the jurisdictions in which purchasers of goods are located, thus ensuring that remote sales do not enjoy tax advantages over local bricks-and-mortar businesses and that states do not suffer tax revenue losses due to the anticipated growth of inter-state e-commerce.

One difficulty with this proposal, as several commentators have noted, is that vendors do not necessarily know the whereabouts of online purchasers, so some system would be needed in order to determine precisely where purchasers are located. Furthermore, requiring vendors to collect and remit sales taxes might place onerous compliance costs on these vendors, due to the fact that there are some 7,600 different tax jurisdictions-states, counties, and cities-in the United States, many of which tax goods and services at different rates, and vendors would be required to know not only the destination of the sale but also the tax rate applied there (McClure, 2000:64). Administrative procedures for registering, filing, paying, and appealing sales taxes also vary from jurisdiction to jurisdiction, imposing further compliance costs on remote sellers. To deal with the issue of compliance costs, the NGA is simultaneously proposing a sweeping simplification of state and local sales taxes-including one sales tax rate per state, streamlined administration and audit requirements, and uniform definitions of the goods and services that may be taxed-thus, in theory, simplifying the collection and remission of sales tax on remote sales. The NGA has therefore effectively concluded that nationwide harmonization of sales taxes is the best way to address the fiscal challenges of ecommerce: "States can no longer 'go it alone' in designing tax policy if they desire a system that operates in sync with the new economy and produces adequate revenue to finance the services needed by their citizens and businesses" (National Governors' Association, 2000:34).

Given that most of the world's e-commerce is still concentrated within the United States, it should not come as a surprise that U.S. states, rather than national governments, are the most vocal advocates of effective taxation of e-commerce. But as the volume of worldwide e-commerce expands, and as a greater proportion of that commerce takes place across international borders, we should expect this issue to become more prominent in international politics as well. The national 
governments that have already expressed their concern about the tax implications of e-commerce invoke precisely the same logic as the member states of the National Governors' Association: namely, that failure to tax e-commerce effectively represents a long-term threat to their respective tax revenues, and more generally to the global tax base. Nor should we expect this concern to diminish with time, given that many countries face rising social expenses in the coming years as the post-World War II demographic bulge enters retirement and old age (Avi-Yonah, 2000b).

On the other hand, it is conceivable that national governments could compensate for lost tax revenues arising from the spread of e-commerce by increasing effective tax rates on less mobile sources, such as payroll taxes on labor, user fees for public services, or even simple poll taxes. ${ }^{17}$ Indeed, one of the striking features in the history of modern taxation is the degree to which states have been able to adjust their tax policies to the shifting characteristics of the ambient economies by changing the targets of taxation and focusing on the revenue streams or stocks that are most readily taxable at a particular time (Ardant, 1971; Tarschys, 1988; Levi, 1988). In practice, however, there are political limits on the degree to which governments can alter the "tax mix," or the composition of different types of taxes within their respective societies (Steinmo and Swank, forthcoming; Rothstein and Steinmo, forthcoming). Substantially shifting the burden of national taxation away from mobile and generally more affluent individuals and enterprises, and toward less mobile and generally less wealthy workers and firms, may make economic sense, but it is a politically costly strategy for democratic governments (as Margaret Thatcher discovered when she instituted a widely unpopular poll tax in Britain in 1990) and therefore unlikely to be embraced by states as a viable alternative to finding new means of taxing mobile commerce and capital. ${ }^{18}$ Indeed, member states of the OECD have already indicated their clear intention to tax international electronic commerce, rather than abandoning it as a tax-free zone, in part because of the continuing need for "revenue required to meet the legitimate expectations of citizens for publicly provided services." 19 In addition, these states have reaffirmed their commitment to the principle of "tax neutrality" in any revision of the international tax regime to accommodate e-commerce, meaning that firms should be subject to similar taxes regardless of whether they are engaged in conventional or electronic forms of commerce. ${ }^{20}$ These decisions coincide with the OECD's broader efforts to combat "unfair tax competition," which is further evidence of states' preference for finding ways to tax mobile sources of income.

Beyond concerns about tax revenue, states may also be driven to demand international taxation of e-commerce in order to create a "level playing field" for their own companies. If the United States, for example, ultimately adopts a system to impose state sales tax on remote sales-which both the National Retail Federation and the Internet Commerce Association believe will happen in the near future (reported in Enos, 2003)-then U.S.-based companies could find themselves at a disadvantage relative to electronic vendors based offshore, whose sales to Americans might not be subject to state sales taxes. ${ }^{21}$ Just as concerns about

\footnotetext{
${ }^{17}$ A "poll tax" is a tax levied equally on every adult in the community.

${ }^{18}$ Guehénno, 1995:11. Although national governments have generally shifted their respective tax mix in the direction of immobile factors, including labor, in the past 25 years, this shift has been relatively small, in the range of a few percentage points of the overall tax burden (Neubig and Poddar, 2000). If anything, many of the scholars who have investigated this question are struck by the degree to which governments have been effectively constrained by domestic politics from shifting tax burdens away from mobile and toward immobile sources (Rothstein and Steinmo, forthcoming).

19 This commitment was made at the OECD Ministerial Conference on "A Borderless World: Realizing the Potential of Electronic Commerce," in October 1998. The conference report is reproduced as OECD, 1998a.

${ }^{20}$ Ibid.

${ }^{21}$ Deloitte and Touche, 1999. Indeed, there are numerous sources of information available to businesses on the tax advantages of moving their e-commerce operations offshore. See, for example, the "Offshore-E-Com.Com Knowledge Base" at http://www.offshore-e-com.com accessed 1 August 2001.
} 
unfair competition between online and bricks-and-mortar businesses have helped to fuel the movement for sales taxes on e-commerce within the U.S., concerns about unfair competition by foreign online vendors may also produce political pressure for the creation of mechanisms to ensure that offshore vendors also collect sales tax on products and services delivered to U.S.-based customers. Although discussions of competition and e-commerce within the United States are still largely focused on the domestic realm, some commentators have already begun to extrapolate this logic to the international setting, and have argued that any solution to the domestic issue of e-commerce taxation "must flow naturally into global economic policy" and "should be harmonious with worldwide taxing schemes" in order to avert unfair competition with overseas retailers (Deloitte and Touche, 1999:15).

The European Union is currently struggling with a similar problem. Instead of a sales tax, EU countries charge a VAT on goods and services, at rates that vary from one country to the next. Under current regulations, EU-based companies collect and remit VAT on all of their sales (regardless of whether the purchasers are residents of the European Union or other countries) including sales of goods and services delivered electronically, such as music and software. But when residents of the EU receive electronic purchases through the Internet from non-EU suppliers, no VAT is charged on the sale, thereby placing EU companies at a disadvantage relative to offshore suppliers. In February 2002, the EU Ministers approved a proposal to overhaul the VAT system as it applies to digital deliveries. ${ }^{22}$ Acknowledging that the existing threat to tax revenues was "very limited for the moment," but arguing that "the growth of e-commerce poses potential long-term problems for tax administrations," the Commission recommended that the VAT be charged only on digital sales to customers located in the EU, and conversely that the VAT should not be charged to European companies that are making electronic sales to non-EU customers (Commission of the European Communities, 2000). Responsibility for collecting and remitting the VAT in such cases would fall to the foreign companies making sales to EU residents. One problem with this plan that several commentators have noted and EU officials have privately acknowledged (see Hargreaves and Leffall, 2000) is that requiring foreign-based companies to collect the VAT is unenforceable: "If just one country or territory failed to support the policy, it would become a haven for suppliers unwilling to pay VAT" (Price, 1999). By contrast, Britain issued a counter-proposal in 2001 to exempt all online sales from the VAT for a two or three year period, in order to allow work to proceed within the OECD on a more global solution to the problem of how to collect indirect taxes on electronic commerce. However, the British proposal was rejected by the other members of the EU, partly on the grounds that exempting e-commerce from VAT would threaten the national tax revenues of European governments (European Information Service, 2001).

Concerns about the long-term fiscal implications of e-commerce, in short, are already leading governments to think about ways of improving existing mechanisms for taxing digital commerce. Thus far, discussions have focused primarily on indirect taxes-including the U.S. state sales tax, and the European VAT-but, as noted earlier, the spread of digital commerce also challenges existing systems of direct taxation including the fundamental principles of source and residency. The anticipated rapid growth of the Internet economy-and the unwillingness of many national and local governments to abandon electronic commerce as a source of tax revenue, even at this relatively early stage in the development of global ecommerce-makes it very unlikely that the Internet will remain a tax-free zone. "Commerce, whether physical or virtual, is going to be taxed," writes Stephen Kobrin. "The questions are how and by whom?" (Kobrin, 1999b).

${ }^{22}$ European Union, 2002. The changes are expected to take effect in July 2003. 


\section{Premise 4: The Taxation of E-Commerce Will Require Extensive International Collaboration and Coordination}

Who will tax e-commerce-and how they will do it-remain to be seen. Nevertheless, the creation of an effective system to tax electronic commerce would almost certainly require extensive international collaboration and coordination. As the European Commission noted in 2000: "E-commerce is, by its nature, a truly global process and no tax jurisdiction, acting in isolation, can resolve all the issues it raises" (Commission of the European Communities, 2000:3). Given sovereignty concerns, resistance to the globalization of taxation from some countries may be fierce, not least from the United States, as we shall see below. Unforeseen shocks to the global economy, major non-economic events such as the terrorist attacks of September 11, 2001, or routine turnover in government administration, could also shape the attitudes of national governments toward the international tax regime and its future evolution. Accordingly, my argument in this section is not that all states will embrace the globalization of taxation immediately or uniformly, but rather that if the world's leading economic powers-including Europe and the United States-conclude that the taxation of cross-border electronic commerce is necessary (premise 3), the practical demands of taxing this commerce will leave them little choice but to accept higher levels of international cooperation and coordination over tax policy (premise 4).

We have already touched upon some of the practical difficulties facing U.S. states and members of the European Union who seek to impose indirect taxes on digital commerce. The principal problems include the creation of a "level playing field" between in-jurisdiction and out-of-jurisdiction vendors, and ensuring that out-ofjurisdiction vendors faithfully collect and remit consumption taxes to the appropriate authorities. Both the EU's new VAT procedures and the National Governors' Association's plan for simplification of sales taxes and state taxation of remote sales presuppose the willingness of legally independent tax authorities to enforce another jurisdiction's tax rules-to ensure that remote vendors pay consumption taxes to the jurisdiction in which the purchaser is located. Such cooperation would be unlikely to take place in the absence of reciprocal enforcement agreements among two or more taxing jurisdictions (since no state has an interest in enforcing another state's tax rules, thereby increasing costs for local vendors, unless they also have something to gain from doing so). It also implies measures-perhaps a combination of inducements and sanctions-to bring recalcitrant jurisdictions into conformity with the taxation regime in order to prevent sellers from relocating to tax havens as a means of evading the collection of consumption taxes. ${ }^{23}$ At the international level, extra-territorial enforcement of national indirect taxes would represent a major incursion into the traditional autonomy of states as taxing entities. Indeed, this type of arrangement could easily be portrayed as a violation of sovereign state rights, and could therefore face considerable political opposition. Nevertheless, some type of reciprocal enforcement mechanism appears to be the natural-and, perhaps, necessary-end point of ongoing efforts within both the European Union and the United States to impose indirect taxes on cross-jurisdictional electronic commerce.

If online vendors are called upon to collect and remit taxes on international digital sales, business groups would probably demand a simplification and harmonization of tax rules across different jurisdictions, since keeping track of

\footnotetext{
23 Some scholars, including Margaret Levi (1988) and John Scholz (1998), point out that measures to enforce compliance with tax policies are less essential in societies with high levels of "trust" in government and in the integrity and fairness of the tax system, because individuals in such societies often comply with tax regulations voluntarily. Even in these relatively "trusting" environments, however, coercive enforcement is necessary to deal with tax evaders. The same would be true at the international level, where "trust" among governments is often lacking.
} 
the regulations in different taxing jurisdictions (and applying these regulations to individual sales according to customer location) would place onerous compliance costs on Internet vendors, and may in fact prevent smaller vendors from selling to international customers. Although the European Union is still in the process of working out its strategy for adjusting the VAT to the circumstances of international e-commerce, plans currently under discussion recognize the need for a simplified tax system-in particular, one that would apply a single set of regulations and consumption tax rates on foreign vendors making sales to EU customers. Also under discussion is a possible mechanism for distributing the tax revenues obtained through the new VAT system to the EU countries in which the electronic products were consumed. These developments reinforce the observation that any system requiring remote vendors to collect and remit consumption taxes will probably require the harmonization of tax policies across jurisdictions or a multilateral mechanism to distribute revenues raised from these taxes, or both. ${ }^{24}$ This is yet another reason why measures to improve the indirect taxation of e-commerce are likely to entail a movement toward greater international coordination of consumption tax policies.

There are two other possible approaches to the indirect taxation of cross-border digital commerce, both of which would also necessitate enhanced international cooperation. The first alternative is the current EU practice of having states collect consumption tax on all sales originating within their territory. As the European Union is discovering, however, this approach is practicable only if other countries also agree to tax in this manner-otherwise, it would penalize locally based businesses at the expense of remote vendors, who would not be charged the tax. The second alternative is to collect consumption taxes directly from consumers, rather than from vendors. This approach is also problematic because governments would have to depend on individual consumers to report their own taxable remote purchases, which would invite widespread tax evasion. Perhaps such a system could work if foreign companies were required to report their sales to local authorities, who would then transmit this information to tax officials in the customer's home jurisdiction-although this arrangement, too, would presumably require the creation of international mechanisms for the collection and sharing of tax information: in short, a transnational tax audit system.

The collection of direct taxes on income and profits generated by e-commerce would also require greater international coordination. The difficulties of redefining "permanent establishment" in a way that would allow national authorities to tax profits generated by e-commerce, and the more general problem of identifying "fixed places of business" in the nonterritorial realm of digital commerce, have led some commentators to recommend that the residence principle be abandoned entirely and that direct taxes on e-commerce be charged only by tax authorities at the source of income-that is, the location at which the income is generated rather than the jurisdiction in which the income producer resides. Any exclusively sourcebased system of taxation, however, would require international mechanisms to sort out complicated jurisdictional issues, including the criteria for determining where the source of income is generated in complex, multi-jurisdictional digital transactions, as well as techniques for resolving inevitable jurisdictional disputes. ${ }^{25}$ Further, methods would have to be devised to enforce source-based tax claims in cases of nonresidents that "do not have a permanent establishment or other

\footnotetext{
${ }^{24}$ Further, there might also be a need for new international mechanisms which would help companies to determine the physical location (and therefore the taxing jurisdiction) of their customers. Currently, companies cannot be sure of where exactly their digital shipments are received.

${ }^{25}$ See, for example, Forst's (1997) suggestions of how the source principle could be applied in new ways to the taxation of international e-commerce, all of which would necessitate the development of new international mechanisms for determining tax jurisdictions, along with enforcement mechanisms.
} 
physical presence in the source state that can essentially serve as collateral for any tax liability" (Doernberg and Hinnekens, 1999:308).

The problems of source-based taxation of e-commerce have led the U.S. Treasury Department to recommend adopting an enhanced residence-based system, on the grounds that,

\begin{abstract}
[i]n the world of cyberspace, it is often difficult, if not impossible, to apply traditional source concepts to link an item of income with a specific geographical location. Therefore, source based taxation could lose its rationale and be rendered obsolete by electronic commerce. By contrast, almost all taxpayers are resident somewhere.... United States tax policy has already recognized that as traditional source principles lose their significance, residence-based taxation can step in and take their place. This trend will be accelerated by developments in electronic commerce where principles of residence-based taxation will also play a major role. (cited in Avi-Yonah, 1997:525)
\end{abstract}

Yet a residence-based system would raise its own set of problems: first, it would likely entail a major shift in tax revenues from poorer to richer countries, given that most e-commerce firms base their operations in developed states. ${ }^{26}$ Second, the residence-based approaches face the difficulty of identifying the residence of firms that are managed from a remote, or several remote, locations (Doernberg and Hinnekens, 1999:331). Almost certainly, any such system would require the development of new international mechanisms for determining the residency status of mobile, decentralized, and "nonterritorial" e-commerce businesses-perhaps on a case by case basis-and for resolving inter-jurisdictional disputes over particular companies' places of residence. These mechanisms would probably need to be multilateral in character, in order to deal with cases of income arising from activities in multiple jurisdictions-which would, in effect, involve a transformation in the existing international tax regime's reliance on separate bilateral treaties.

Some commentators have gone even further and advocated a centralized procedure for allocating worldwide profits of multinational enterprises among taxing jurisdictions according to a pre-set formula-which might mix source and residence factors - similar to the systems used in the United States and Canada for apportioning corporate tax profits among states and provinces. ${ }^{27}$ Any "formula apportionment" system at the worldwide level, however, would face three challenges, each requiring extensive cooperation among national taxing authorities. First, it would be necessary to determine which entity or entities would be taxed, including consideration of enterprises on a case-by-case basis to establish which subsidiaries or branches of the enterprise should be considered as part of the global taxable entity. Second, officials would have to calculate the global profits of each enterprise-a task that becomes difficult when different jurisdictions have different rules for measuring income and loss. Third, and most obviously, a formula for apportioning tax revenues would be required. While the third task-the negotiation of a formula-might be realized in a single multilateral conference or series of conferences, it seems unlikely that the first two tasks could be accomplished in the absence of a permanent or semipermanent professional administration, given the ongoing nature of the work and the complexity of the judgments required.

In sum, whether the taxation of international e-commerce is pursued through an enhanced source-based system, an enhanced residence-based system, or a formula

\footnotetext{
${ }^{26}$ McClure, 1997:361. Forst (1997) points out, in addition, that since more e-commerce firms reside in the United States than in any other country, America's developed-country trading partners would also be unlikely to accept a shift to a residence-based taxation scheme.

${ }^{27}$ See the references in McClure, 1997:418.
} 
apportionment system, a considerable broadening and strengthening of the international tax regime will almost certainly be necessary. It is difficult to imagine any such arrangement that would not involve the creation of some form of permanent international tax institution-perhaps not a tax collection agency, but more likely, a tax coordination agency that would monitor the implementation of multilateral tax agreements, collect and disseminate data on multinational and "nonterritorial" enterprises in response to the growing opportunities for international tax avoidance, and adjudicate inter-jurisdictional tax disputes. This type of organization could conceivably develop within the institutional structures of an existing agency such as the OECD or the WTO, or it could take the form of a stand-alone World Tax Organization (Tanzi, 1999). But even if no new formal institutions are created, the challenges posed by the rise of e-commerce appear to lead inexorably toward more extensive and multilateral coordination of global taxation policies.

This, at least, is the logic that national governments will likely face as they confront the need for effective taxation of cross-border e-commerce. How governments ultimately respond to the pressures described above cannot be known. Some states may resist the idea of expanding the international tax regime more than others, not least because the very centrality of revenue-gathering to the idea of state sovereignty might foster opposition to the reduction of national autonomy over tax policy. The posture of the United States-the world's largest economy and most powerful actor-is obviously crucial. At times the U.S. government has been ambivalent and sometimes downright hostile to the idea of coordinating its tax policies with other states. When the administration of George W. Bush came into power in 2001, for example, it initially backed away from the preceding administration's support for the OECD's "harmful tax competition" initiative on the grounds that tax competition across states was not inherently harmful. ${ }^{28}$ Speaking in May 2001, former Treasury Secretary Paul O'Neill stated that the "United States does not support efforts to dictate to any country what its own tax rates or tax system should be and will not participate in any initiative to harmonize world tax systems. The United States simply has no interest in stifling the competition that forces governments like businesses to create efficiencies" (United States Department of the Treasury, 2001).

But the Bush administration began to shift its position following the terrorist attacks of September 11, 2001 and widespread revelations about corporate fraud in the U.S. The first sign of change was an announcement by the Treasury Department shortly after September 11 that it was "reassessing" U.S. policy toward the OECD's harmful tax initiative (Walsh, 2001). The initial motivation for this shift was concern that Osama bin Laden, the alleged perpetrator of the September 11 attacks, had used tax havens to launder money that subsidized his terrorist activities. This policy change accelerated when news emerged of widespread accounting irregularities in some of America's biggest corporations, most notably Enron, in early 2002. The Bush administration and both houses of Congress began to propose measures aimed at preventing U.S. companies from using overseas tax havens to avoid paying U.S. taxes, explicitly rejecting the administration's earlier claim that international tax competition was healthy, and arguing instead that this activity represented a destructive form of corporate tax evasion. ${ }^{29}$ These events suggested that even an administration that was ideologically hostile to the regulation of tax havens could reorient its policies in response to overriding

\footnotetext{
${ }^{28}$ Within the OECD, Switzerland and Luxemburg have also opposed the enforcement of sanctions by the OECD against "tax havens."

${ }^{29}$ Among other things, the Bush administration stated in June 2002 that it would support a temporary moratorium on U.S. corporations shifting their legal addresses overseas to reduce their tax liabilities (Kirchhoff, 2002), while committees of both the House of Representatives and the Senate voted to bar the federal government from awarding contracts to U.S. companies that use foreign tax havens (Morgan, 2002; Milligan, 2002).
} 
exigencies. It is entirely conceivable that fiscal pressures arising from the expected growth of cross-border electronic commerce could produce a similar outcome, effectively compelling the U.S. government to embrace greater multilateral coordination of tax policy as the only practicable means of taxing e-commercejust as some of the most economically conservative U.S. governors, including Utah's Michael Leavitt, have advocated the harmonization of state sales taxes in order to stanch revenue losses arising from cross-state electronic commerce.

That said, the tension between concerns over sovereignty and the demands of effective e-commerce taxation will probably take many years to resolve, and indeed may never be fully resolved. This tension is already visible in the OECD's analysis of the implications of electronic commerce for existing methods of taxation. On one hand, the OECD states that any changes to the existing tax regime must preserve "fiscal sovereignty," or the ability of national governments to write and administer their own tax laws; and the organization insists that its proposed International Dialogue on Taxation-which will bring together states and international agencies that are interested in tax policy and administration- "will not at any stage have any power to make, enforce or mediate binding tax rules" (OECD, 2001:11; OECD, 2002:1). At the same time, however, the OECD has concluded that the effective taxation of cross-border electronic commerce is necessary, and that it will require "substantially greater levels of international administrative cooperation... between revenue authorities" (OECD, 2001:21,38). One of the principal challenges for the OECD and its member states, therefore, will be to balance the conflicting demands for effective taxation and for state autonomy.

Concerns about popular sovereignty might also generate opposition to the transnational harmonization of tax policy. Taxes are not merely revenue-generating instruments; they also reflect societal decisions on "a wide range of social issues from beliefs about social spending to the role of government to the distribution of wealth and income" (Kobrin, 2000:24; see also Braun, 1975:246-248). As Sol Picciotto observes, "Taxation is the point of most direct intervention between government and citizens, the state and the economy" (Picciotto, 1992:xiii). Disputes over tax policy have sparked rebellions throughout modern history (Ardant, 1975:167), some of which, including the American Revolution, have been driven by demands for greater popular control over taxation, or the principle of "no taxation without representation." Thus, the globalization of taxation might raise questions about the democratic accountability of any new international tax arrangement (no global taxation without representation?) in addition to concerns about state sovereignty (Keohane, 2001; Nye, 2001). If so, then protest movements that have criticized the "undemocratic" character of the World Trade Organization, for example, could play a significant role in the politics of international tax harmonization as well (Paris, 2003).

\section{The Globalization of Taxation}

These four premises lead to the following conclusion: We have reached what might be a turning point in the history of taxation. Until now, national governments have designed and administered their tax policies in near-splendid isolation from one another. Apart from the minimalist and voluntary constraints of the OECD's Model Tax Convention and a network of bilateral treaties to prevent double taxation, states have remained largely autonomous agents of taxation, even as the globalization of production and commerce (and, to a lesser extent, the globalization of business regulation ${ }^{30}$ ) have gathered momentum. But the rise of digital

\footnotetext{
${ }^{30}$ See Braithwaite and Drahos, 2000. The authors define the globalization of business regulation as (1) "globalization of norms, standards, principles and rules that govern commerce" and (2) the "globalization of their enforcement" (p. 10).
} 
commerce is already exposing the inadequacies of the existing tax regimeinadequacies that will only become clearer and more problematic as the scale of ecommerce expands, and as states come to realize that technological changes in the nature of commerce require considerably higher levels of international coordination in the field of taxation.

This conclusion is, of course, a conjecture that might turn out to be wrong, not only because further changes in communications technology could alter the nature of cross-border commerce in a manner that diminishes the fiscal and technical challenges raised by the growth of electronic commerce, but also because governments themselves could develop new technologies for tracking and taxing transactions. Furthermore, the four premises of my argument rest on several secondary assumptions, including that the revenue losses arising from the failure to tax cross-border electronic commerce will be sufficiently large to compel states to develop transnational mechanisms for taxing this commerce, and that states will not choose instead to compensate for this loss through alternative methods of national taxation, such as poll taxes-in other words, that states will ultimately react to the growth of e-commerce in a manner paralleling state governments within the U.S. All of these assumptions are contestable, but if they are correct, movement toward greater transnational harmonization of tax policy should be expected.

\section{Implications for the State}

The globalization of taxation, should it come to pass, would have important implications for our understanding of state sovereignty. As we noted earlier, the modern state came into existence and achieved dominance largely as a result of its ability to collect taxes. The fiscal crisis of the European feudal system elicited efforts to raise revenues more effectively, which in turn contributed to the formation of centralized state bureaucracies, thereby increasing the capacity of states to extract further taxes, and helping the modern territorial states to prevail over competing political forms. The history of taxation and the state lends support to Schumpeter's claim that fiscal conditions shape the development of political institutions-by shifting political authority toward whatever institutional forms are best suited to the tasks of assessing and collecting taxes. Territorial states, I have argued, are not particularly well-suited to the taxation of nonterritorial electronic commerce. Consequently, as electronic commerce grows in volume, states will experience a corresponding decline in their ability to tax global commerce. More precisely, states are likely to experience a decline in their autonomous taxing abilities, since any measures developed to tax electronic commerce will, for the reasons spelled out above, almost certainly have to involve the establishment of collective, multilateral arrangements among many states. Increased levels of coordination and harmonization among national tax policies would involve a partial shift of de facto authority over taxation away from individual states and toward whatever international arrangement is established to coordinate this taxation.

Viewed against the backdrop of the history of taxation and the state, such a development would represent yet another instance of fiscal conditions shaping the evolution of global political forms. Schumpeter pushed this argument to an extreme. "If the tax state were to fail and another form of providing for the wants of the community ensued," he wrote, “... what we call the modern state would itself change its nature" (Schumpeter, 1991[1918]). Today, nearly a century after he wrote these lines, the modern state as a political form has yet to experience a sustained fiscal crisis of this magnitude, and shows no sign of imminent "failure" as a taxing entity. As the world's primary taxing entity, in other words, the modern territorial state is not about to disappear. On the contrary, it will almost certainly "persist at the core of governance arrangements in the contemporary globalizing 
world" for decades and perhaps centuries to come, including in the domain of taxation (Scholte, 1997:428).

Nevertheless, the underlying logic of Schumpeter's argument - that political forms tend to mirror prevailing technological and economic conditions, and can be outmoded by changes in these conditions-does help to explain current developments in world politics, not just in the domain of taxation but in other areas as well. Technological advances have given rise to global processes and issues from trade to pollution that are beyond the scope of individual states to manage effectively. In response, states have constructed an ever-growing network of regulatory arrangements at the international level, including "informal and formal international institutions, regimes, organizations, and regional trading blocs" (Deibert, 1997:157; see also Zacher, 1992; Picciotto, 1996; Reinicke, 1998; Young, 1999). These arrangements typically entail a pooling of the state's regulatory powers over particular issues. States both gain and lose through this process: they lose a measure of individual autonomy, but they also gain collective capabilities to address certain problems that would otherwise escape their control. (Indeed, the globalization of regulation can be viewed, in part, as an effort by states to restore their effective authority in domains that have grown beyond the modern system of exclusive and parcellized sovereignty, and thus as an attempt to prevent the very obsolescence of the territorial state that Schumpeter warned about.) But it is also the case that states pursuing this path are in effect creating new centers of political authority that are not modern territorial states, and in so doing they are changing the architecture of the international system.

At one level, the creation of new centers of de facto political authority at the international level seems to blur "the distinction between external and internal affairs, between international and domestic policy," which are defining characteristics of the modern states system (Held, 1995:90). More fundamentally, the emergence of these new loci of authority may also chip away at established assumptions about the relationship between physical space and political authority (Ruggie, 1993:171). The concept of the modern state is inherently tied to notions of centralized authority and bounded territory, which emerged out of the more fluid political system of feudalism (Poggi, 1978). In contrast to the transition from feudalism to the modern state, the present-day phenomenon of the globalization of regulation involves the decentralization, rather than the centralization, of authority. The result of this process is a complex network of formal and informal transnational regimes which, unlike the state, lacks central control and geographical borders, but nonetheless exercises de facto political authority. The globalization of governmental regulation, in other words, seems to involve an "unbundling" of the political-territorial assumptions that have traditionally underpinned the modern states system (Jayasuriya, 1999).

Some scholars describe this process as the "internationalization of the state" because it entails the formation of a decentralized, nonterritorial structure of political authority at the international level that performs functions traditionally associated with the role of the modern territorial state. ${ }^{31}$ In this view, the "state" is defined as a system of governance and rule that need not take the form of a formal organization exercising exclusive authority over a bounded territory (Benjamin and Duvall, 1985). The merger of territoriality and centralized authority within the modern state is only one of many possible ways in which political authority has been, or could be, organized (Murphy, 1996). As Alexander Wendt writes, "In the Westphalian system [of modern territorial states], state agents and authority structures did coincide spatially....But the two concepts need not correspond in this way: political authority could in principle be international and decentralized"

${ }^{31}$ Wendt ,1994. For variations of this argument see Shaw, 2000; Cox, 1987:253-265; Glassman, 1999; Picciotto, 1990 
(Wendt, 1994:392, emphasis in original). Limiting the definition of the state to political forms based on "linear, exclusive boundaries" deflects attention away from the new structures of political authority that may not resemble the modern state, but that nevertheless appear to be playing an increasingly important and "statelike" role in world politics (Forsberg, 1996:364; Walker, 1990; Paul, 1999). Thus, by defining the growing network of regulatory arrangements at the global level as an international state, Wendt seeks to highlight the degree to which the governance functions of the modern state are being performed at the international level, and to escape what another scholar calls the "territory trap" in theorizing about governance (Agnew, 1994), or the tendency of commentators "to visualize longterm challenges to the system of states only in terms of entities that are institutionally substitutable for the [modern] state" (Ruggie, 1993:143). According to this line of argument, as the network of global regulatory arrangements grows, the international state is slowly but steadily taking its place in world politics alongside traditional territorial states-not replacing the modern state, but coexisting with it (Shaw, 2000:192).

The globalization of taxation fits into this larger process and represents a potentially enormous addition to this process. The rise of electronic commerce, I have argued, will likely spur the movement toward the globalization of taxation-a development that would represent a historic shift in the balance of political authority between territorial states and the international state. Apart from national defense, no activity is more central to the idea of the modern state than that of taxation. Scholars from the $16^{\text {th }}$ century onward have treated taxation as a special prerogative and occupation of the state. Jean Bodin, who is widely regarded as the first theorist of the modern state, described taxation as one of the "unique attributes of sovereign power" (quoted in Wolfe, 1968:268). In the words of sociologist Fritz Karl Mann, "taxation is the inseparable twin of the modern state" (Mann, 1943:225). Devolution of de facto authority over taxation from the exclusive domain of the territorial state to a transnational tax regime would be an important substantive and symbolic development in the gradual internationalization of the state.

Political opposition to the globalization of taxation is, as we have noted, certainly possible. In the end, however, changes in the technology, mobility, and scope of global commerce will likely leave states with little choice but to increase the coordination and harmonization of their respective tax policies. The nonterritorial character of electronic commerce poses a particular challenge to existing systems of taxation and to the minimalist international tax regime whose principal features were established at the end of World War I-a challenge that will soon have to be addressed. Splendid isolation is rapidly becoming an untenable stance for states in the realm of taxation. And to the extent that de facto taxing authority migrates upward from the state to a new global tax arrangement, the emerging international state will have gained an important additional function. Schumpeter's thesis- that material conditions, including changes in technology and economics, influence the evolution of political forms-seems even more relevant today than it was in 1918.

\section{Conclusion}

Electronic commerce represents a qualitatively new form of commerce that defies many of the assumptions upon which existing national tax systems and the international tax regime are based, including the notion that transactions can be located in physical space. As a result, there is a growing disjuncture between the international tax regime and the nonterritorial character of digital commerce. JeanMarie Guéhenno captures the essence of this problem: "When there is no longer a territorial imperative, when the place of residence and the investment are no longer a given but a choice, when added value is generated in too abstract a fashion 
for its creation to be assigned a precise location, taxation is no longer a sovereign decision" (Guéhenno, 1995:10). Guéhenno errs, however, in asserting that taxation cannot remain a "sovereign" decision. If one accepts that effective sovereignty, or what I have called de facto political authority, can be and is being disaggregated and internationalized, then sovereignty over taxation could conceivably shift from territorial states to a decentralized "international state." Indeed, this process appears already to be under way, and there are strong indications that it will accelerate in the years to come.

\section{References}

Agnew, J. A. (1994) "Timeless Space and State-Centrism: The Geographical Assumptions of International Relations Theory." In The Global Economy as Political Space, edited by S. J. Rosow, N. Inayatullah and M. Rupert, pp. 87-106. Boulder, CO: Lynne Rienner.

ANDerson, P. (1974) Lineages of the Absolutist State. London: NLB.

Ardant, G. (1971) Histoire de l'Impôt: De l'Antiquité au XVIIe Siècle. Paris: Fayard.

ARdant, G. (1975) "Financial Policy and Economic Infrastructure of Modern States and Nations." In The Formation of National States in Western Europe, edited by C. Tilly, pp. 164-242. Princeton, NJ: Princeton University Press.

Avi-YonaH, R. S. (1997) International Taxation of Electronic Commerce. Tax Law Review 52(3): $507-555$.

Avi-Yonah, R. S. (2000a) Commentary. Tax Law Review 53(2):167-175.

Avi-YonaH, R. S. (2000b) Globalization, Tax Competition, and the Fiscal Crisis of the Welfare State. Harvard Law Review 113(7):1573-1676.

BEAN, R. (1973) War and the Birth of the Nation State. Journal of Economic History 23(1):203-221.

Benjamin, R., And R. Duvall (1985) “The Capitalist State in Context." In The Democratic State, edited by R. Benjamin and S. L. Elkin, pp. 19-31. Lawrence: University of Kansas Press.

Braithwaite, J., And P. Drahos (2000) Global Business Regulation. Cambridge: Cambridge University Press.

Braun, R. (1975) “Taxation, Sociopolitical Structure, and State-Building: Great Britain and Brandenburg-Prussia." In The Formation of National States in Western Europe, edited by C. Tilly, pp. 243-327. Princeton, NJ: Princeton University Press.

Bruce, D., And W. F. Fox (2000) E-Commerce in the Context of Declining Sales Tax Bases. National Tax Journal 53(4):1373-1388.

Commission of the european communities (2000) "Proposal for a Council Directive Amending Directive 77/388/EEC As Regards the Value Added Tax Arrangements Applicable To Certain Services Supplied by Electronic Means." Document no. COM(2000) 349 final (June 6).

Cox, R. W. (1987) Production, Power, and World Order: Social Forces in the Making of History. New York: Columbia University Press.

Deibert, R. J. (1997) Parchment, Printing, and Hypermedia: Communication in World Order Transformation. New York: Columbia University Press.

Deloitte And Touche (1999) "Establishing a Framework to Evaluate E-Commerce Tax Policy Options." Report of the E-Commerce Taxation Roundtable, 1 October 1999, University of California, Berkeley.

DoernberG, R. L., And L. Hinnekens (1999) Electronic Commerce and International Taxation. The Hague: Kluwer Law International.

ECONOMist (1997) “The Disappearing Taxpayer” (May 31).

Economist (2001a) “Older, Wiser, Webbier” (June 28).

Economist (2001b) “The Internet, Untethered" (October 11).

emARKETER (2001) “The Global Report," http://www.emarketer.com/ereports/eglobal/, accessed on 1 August 2001.

emarketer (2003) “Worldwide B2B E-Commerce to Surpass \$1 Trillion By Year's End,:” http:// www.emarketer.com/news/article.php?1002125, accessed on 29 April 2003.

ENos, L (2000a) “China to Tax E-Commerce.” E-Commerce Times (July 24), http://www.ecommercetimes.com/perl/story/?id $=3850$.

EnOS, L (2000b) "Net Sales Tax Looms Larger." E-Commerce Times (October 27), htp://www.ecommercetimes.com/perl/story/?id $=4660$.

Enos, L (2001) "Study-Online Sales Tax: Who Cares?" E-Commerce Times (May 2), http:// www.ecommercetimes.com/perl/story/?id $=9394$. 
Ernst and Young (2001) Global Online Retailing: An Ernst and Young Special Report. http://www.ey.com/ global/vault.nsf/US/2001_Retail_Study/\$file/GOR.pdf.

Ertman, T. (1997) Birth of the Leviathan: Building States and Regimes in Medieval and Early Modern Europe. Cambridge: Cambridge University Press.

EuropeAn information SERvice (2001) "European Report,” no. 2599 (June 9).

EuROPEAN UNiON (2002) "Results of Council of Economics and Finance Ministers, Brussels, 12 February 2002-Taxation." MEMO/02/22 (February 13).

Financial times (2002) "Wireless World Offers True Laptop Mobility" (March 13).

ForRester RESEARCH (2002) "Worldwide E-Commerce Growth.” http://www.forrester.com/ER/Press/ ForrFind/0,1768,0,00.html (accessed 30 March 2002).

ForsberG, T. (1996) Beyond Sovereignty, Within Territoriality: Mapping the Space of Late-Modern (Geo)Politics. Conflict and Cooperation 31(4):355-386.

Forst, D. L. (1997) The Continuing Vitality of Source-Based Taxation in the Electronic Age. Tax Notes International 15(Nov. 3):1467-1471.

Garrett, G. (1998) Global Markets and National Politics: Collision Course or Virtuous Circle? International Organization 52(4):787-824.

Glassman, J. (1999) State Power Beyond the "Territory Trap": The Internationalization of the State. Political Geography 18:669-696.

Government of australia (1997) Tax and the Internet. Discussion Report of the Australian Taxation Office Electronic Commerce Project (August).

Government of australia (1999) Tax and the Internet, Second Report. Second Report of the Australian Taxation Office Electronic Commerce Project Team on the Opportunities and Challenges of Electronic Commerce for Tax Administration (December).

Government of CANAda (1998) Electronic Commerce and Canada's Tax Administration. A Report to the Minister of National Revenue from the Minister's Advisory Committee on Electronic Commerce. Ottawa: Minister of Revenue.

Guétenno, J. M. (1995) The End of the Nation-State. Minneapolis: University of Minnesota Press.

Hampton, M. (1996) The Offshore Interface: Tax Havens in the Global Economy. Basingstoke, U.K.: Macmillan.

Hargreaves, D., and J. Leffall, (2000) “Online Tax Plan Angers U.S. Groups.” Financial Times, 8 June.

Held, D. (1995) Democracy and the Global Order: From the Modern State to Cosmopolitan Governance. Stanford, CA: Stanford University Press.

Hellerstein, W. (1997) State Taxation of Electronic Commerce. Tax Law Review 52(3):425-505.

Hoffman, P. T. and K. Norberg, eds. (1994) Fiscal Crises, Liberty, and Representative Government. Stanford, CA: Stanford University Press.

HowiE, C. (2000) "Internet Imports Likely To Face Tax Clampdown," The (Wellington) Dominion (November 9).

InTERnATIONAL TELECOMMUNicATION UNiON (2003) "Key Global Telecom Indicators for the World Telecommunication Service Sector." http://www.itu.int/ITUD/ict/statistics/at_glance/KeyTelecom99.html, accessed on 20 April 2003.

Jackson, R. (1999) Sovereignty in World Politics: A Glance at the Conceptual and Historical Landscape. Political Studies 48:431-456.

Jayasuriya, K. (1999) Globalization, Law, and the Transformation of Sovereignty: The Emergence of Global Regulatory Governance. Indiana Journal of Global Legal Studies 6(2):425-455.

Johnson, D. R., And D. G. Post (1999) "The Rise of Law on the Global Network." In Borders in Cyberspace: Information Policy and the Global Information Infrastructure, edited by B. Kahin and C. Nesson, pp. 3-47. Cambridge, MA: Harvard University Press.

Keohane, R. O. (2001) Governance in a Partially Globalized World. American Political Science Review 95(1):1-13.

Keohane, R. O., And J. S. Jr Nye (2000) Power and Interdependence: World Politics in Transition, 3rd ed. New York: Longman.

Kirchhoff, S. (2002) "Bush Backs Tax-Haven Moratorium.” Boston Globe, 7 June.

Kobrin, S. J. (1999a) "Back to the Future: Neomedievalism and the Postmodern Digital World Economy." Department of Management, The Wharton School, University of Pennsylvania.

Kobrin, S. J. (1999b) “The Tax Man Cometh.” Worldlink (September/October), http://backissues.worldlink.co.uk/articles/08091999111756/10.htm.

Kobrin, S. J. (2000) “'There's No There, There': Gertrude Stein and the Governance of Cyberspace.” Department of Management, The Wharton School, University of Pennsylvania (April).

Krasner, S. D., ed. (1982) International Regimes. Ithaca, NY: Cornell University Press. 
Latin Finance (2001) "Broadband Traffic Boom" (June).

Levi, M. (1988) Of Rule and Revenue. Berkeley, CA: University of California Press.

López-Bassols, V., AND G. Vickery (2001) “The Truth Behind the Web." OECD Observer, 14 January.

Mann, A. (1997) Finding a Nexus for Nonperformance of Services: The Assignment of Primary Taxing Authority Under the OECD Model. Emory International Law Review 11(1) http:// www.law.emory.edu/EILR/volumes/spg97/MANN.html.

Mann, C. L. (2000) Global Economic Commerce. Washington, DC: Institute for International Economics.

Mann, F. K. (1943) The Sociology of Taxation. Review of Politics 5(2):225-235.

McClure, C. E. JR. (1997) Taxation of Electronic Commerce: Economic Objectives, Technological Constraints, and Tax Laws. Tax Law Review 52(3):269-424.

McClure, C. E. JR. (2000) “The Taxation of Electronic Commerce: Background and Proposal.” In Public Policy and the Internet: Privacy, Taxes, and Contract, edited by N. Imparato, pp. 49-113. Stanford, CA: Hoover Institution Press.

Mikesell, J. L. (2000) Remote Vendors and American Sales and Use Taxation: The Balance Between Fixing the Problem and Fixing the Tax. National Tax Journal 53(4): $1273-1285$.

Milligan, S. (2002) "Senate Takes Aim at Offshore Tax Havens." Boston Globe, 1 August.

MishrA, R. (1999) Globalization and the Welfare State. Cheltenham, UK: Edward Elgar.

Morgan, D. (2002) “House Panel Targets U.S. Firms Using Foreign Tax Havens.” Washington Post, 10 July.

Mosley, L. (2000) Room to Move: International Financial Markets and National Welfare States. International Organization 54(4):737-773.

Murphy, A. B. (1996) "The Sovereign State System as Political-Territorial Ideal." In State Sovereignty as a Social Construct, edited by T. J. Biersteker and C. Weber, pp. 81-120. Cambridge: Cambridge University Press.

National Governors ' Association (2000) Governance in the New Economy, Authored by R. C. Scheppach AND F. SHAFroth. Washington, DC: National Governors' Association.

Neubig, T., And S. PodDar (2000) Blurred Tax Boundaries: The New Economy's Implications for Tax Policy. Tax Notes (28 August): 1153-1161.

NyE, J. S. JR. (2001) Globalization's Democratic Deficit: How to Make International Organizations More Accountable. Foreign Affairs (July/August):2-6.

OECD [Organization for Economic Cooperation and Development] (1997) "Measuring Electronic Commerce." Document OCDE/GD(97)185. Paris: OECD.

OECD [Organization for Economic Cooperation and Development] (1998a) Electronic Commerce Taxation Framework Conditions. A Report by the Committee on Fiscal Affairs, As Presented to Ministers at the OECD Ministerial Conference, "A Borderless World: Realizing the Potential of Electronic Commerce," 8 October.

OECD [Organization for Economic Cooperation and Development] (1998b) Harmful Tax Competition: An Emerging Global Issue. Paris: OECD.

OECD [Organization for Economic Cooperation and Development] (2000) Toward Global Tax Cooperation: Progress in Identifying and Eliminating Harmful Tax Competition. Report to the 2000 Ministerial Council Meeting and Recommendations by the Committee on Fiscal Affairs. Paris: OECD.

OECD [Organization for Economic Cooperation and Development] (2001) Taxation and Electronic Commerce: Implementing the Ottawa Taxation Framework Conditions. Paris: OECD.

OECD [Organization for Economic Cooperation and Development] (2002) "Developing the International Dialogue on Taxation" (13 March). Reproduced on the OECD website: http:// www.oecd.org/pdf/M00027000/M00027259.pdf, accessed on 31 March 2002.

Oxfam (2000) “Tax Havens: Releasing the Hidden Billions for Poverty Eradication.” Oxfam G.B. Policy Paper. Oxford, U.K.: Oxfam.

Palan, R. (2002) Tax Havens and the Commercialization of State Sovereignty. International Organization 56(1):151-176.

PARIS, R. (2003) "Global Villagers At the Gates: A Functionalist Theory of International Democracy," paper presented at the annual convention of the International Studies Association, Portland, Oregon, February 25-March 1, 2003.

Paul, D. (1999) Sovereignty, Survival and the Westphalian Blind Alley in International Relations. Review of International Studies 25(2):217-231.

Picciotto, S. (1990) The Internationalization of the State. Review of Radical Political Economics 22(1):28-44. 
Picciotto, S. (1992) International Business Taxation: A Study in the Internationalization of Business Regulation. New York: Quorum Books.

Picciotto, S. (1996) "The Regulatory Criss-Cross: Interaction Between Jurisdictions and the Construction of Global Regulatory Networks." In International Regulatory Competition and Coordination, edited by W. Bratton, pp. 89-123. Oxford: Clarendon Press.

PogGi, G. (1978) The Development of the Modern State: A Sociological Introduction. Stanford, CA: Stanford University Press.

Price, C. (1999) “Government 'May Lose £10bn VAT on E-Trade’: Passion for Online Shopping Sets Tax-Tracking Challenge." Financial Times, 30 August.

ReInicke, W. H. (1998) Global Public Policy: Governing Without Government? Washington, DC: Brookings Institution.

Rosenau, J. N. (1990) Turbulence in World Politics: A Theory of Change and Continuity. Princeton, NJ: Princeton University Press.

Rosenbloom, H. D. (2000) International Tax Arbitrage and the "International Tax System". Tax Law Review 53(2): 137-166.

Rothstein, B., AND S. Steinmo (forthcoming) "Restructuring Politics: Institutional Evolution and the Challenges of Modern Welfare States." In Restructuring the Welfare State, edited by B. Rothstein and S. Steinmo. New York: Palgrave.

Ruggie, J. G. (1993) Territoriality and Beyond: Problematizing Modernity in International Relations. International Organization 47(1):139-174.

Samuels, L. B., And D. C. Kolb (2001) The OECD Initiative: Harmful Tax Practices and Tax Havens. Taxes 79(3):231-260.

Scholte, J. A. (1997) Global Capitalism and the State. International Affairs 73(3):427-452.

Scholz, J. T. (1998) “Trust, Taxes and Compliance." In Trust and Governance, edited by V. Braithwaite and M. Levi, pp. 135-166. New York: Russell Sage Foundation.

Schulze, G. G., And H. W. Ursprung (1999) Globalization of the Economy and the Nation State. World Economy 22(May):295-352.

Schumpeter, J. A. (1991) "The Crisis of the Tax State” (1918). In Joseph A. Schumpeter: The Economics and Sociology of Capitalism, edited by R. Swedberg. Princeton, NJ: Princeton University Press.

Shaw, M. (2000) Theory of the Global State. Cambridge, U.K.: Cambridge University Press.

Spruyt, H. (1994) The Sovereign State and Its Competitors: An Analysis of Systems Change. Princeton, NJ: Princeton University Press.

Steinmo, S., And D. Swank (forthcoming) The New Political Economy of Taxation. American Journal of Political Science.

Strange, S. (1996) The Retreat of the State: The Diffusion of Power in the World Economy. Cambridge: Cambridge University Press.

Strayer, J. (1970) On the Medieval Origins of the Modern State. Princeton, NJ: Princeton University Press.

TAlisman, J. (2000) "Challenges for Tax Policy in a Global Economy.” Remarks to the IRS/GW Annual Institute on Current Issues in International Taxation, Washington, D.C., 8 December. Reproduced on the Department of the Treasury's website, http://www.treas.gov/press/releases/ ps1068.htm, accessed 3 August 2001.

TAnzI, V. (1999) "Is There a Need for a World Tax Organization?” In The Economics of Globalization: Policy Perspectives from Public Economics, edited by A. Razin and E. Sadka, pp. 173-186. Cambridge: Cambridge University Press.

TAnZI, V. (2000) “Globalization, Technological Developments, and the Work of Fiscal Termites.” IMF Working Paper document no. WP/00/181 (November)

TARschys, D. (1988) Tributes, Tariffs, Taxes and Trade: The Changing Sources of Government Revenue. British Journal of Political Science 18(1): 1-20.

UNCTAD [United Nations Conference on Trade and Development] (2000) "Building Confidence: Electronic Commerce and Development.” Document UNCTAD/SDTE/MISC.11.

United STATES DePartment of COMmerce (2001) E-Stats (7 March), http://www.census.gov/eos/www/ papers/estatstext.pdf.

United STATES Department Of COMmerce (2002) "Retail E-Commerce Sales in Fourth Quarter 2001 were $\$ 10.0$ Billion, Up 13.1 Percent from Fourth Quarter 2000.” Census Bureau Reports, U.S. Census Bureau website: http://www.census.gov/mrts/www/current.html, accessed 30 March.

United states department of the treasury (2001) “Treasury Secretary O'Neill Statement on OECD Tax Havens.” Press release no. PO-366, May 10, U.S. Treasury Department website: http:// www.ustreas.gov/press/releases/po366.htm, accessed 11 August 2002. 
United states general accounting office (2000) "Sales Taxes: Electronic Commerce Growth Presents Challenges; Revenue Losses Are Uncertain.” Document no. GAO/GGD/OCE-00-165 (June).

United states Government (1996) Selected Tax Policy Implications of Global Electronic Commerce. Washington, DC: Department of the Treasury, Office of Tax Policy.

Van Creveld, M. (1999) The Rise and Decline of the State. Cambridge: Cambridge University Press.

Walker, R. B. J. (1990) "Sovereignty, Identity, Community." In Contending Sovereignties, edited by R. B. J. Walker and S. Mendlovitz, pp. 159-185. Boulder, CO: Lynne Rienner.

Walsh, C. (2001) "America Wants to Scrap the World's Tax Havens." Observer, 23 September.

Webber, C., AND A. Wildavsky (1986) A History of Taxation and Expenditure in the Western World. New York: Simon and Schuster.

Wendt, A. (1994) Collective Identity Formation and the International State. American Political Science Review 88(2):384-396.

Wolfe, M. (1968) Jean Bodin on Taxes: The Sovereignty-Taxes Paradox. Political Science Quarterly 83(2):268-284.

WoOdward, G. T. (2001) “Economic Analysis of Taxing Internet and Other Remote Sales." Statement before the Senate Finance Committee by G. Thomas Woodward, Assistant Director for Tax Analysis, Congressional Budget Office, August 1, 2001. Downloaded from the Congressional Budget Office's website on 1 August 2001: http://www.cbo.gov/showdoc.cfm?index $=$ $2961 \&$ sequence $=0 \&$ from $=5$.

Young, O. R. (1999) Governance in World Affairs. Ithaca, NY: Cornell University Press.

Zacher, M. W. (1992) "The Decaying Pillars of the Westphalian Temple: Implications for International Order and Governance." In Governance Without Government: Order and Change in World Politics, edited by J. Rosenau and E. O. Czempiel, pp. 58-101. London: Macmillan. 